\title{
PEMANFAATAN ARANG AKTIF BIJI KAPUK (Ceiba pentandra L.) SEBAGAI ADSORBEN LOGAM TIMBAL (Pb)
}

\author{
The Use of Activated Charcoal of Cotton Seeds (Ceiba pentandra L.) as an \\ Adsobent for Lead (Pb)
}

\author{
*Sri Wahyuni, Purnama Ningsih, dan Ratman \\ Pendidikan Kimia/FKIP - Universitas Tadulako, Palu - Indonesia 94118 \\ Recieved 13 September 2016, Revised 13 Oktober 2016, Accepted 16 November 2016
}

\begin{abstract}
Lead is a heavy metal that has been a problem particulary in the aquatic environment. This reseach is an effort to reduce these problems by using adsorption method that utilizes an adsorbent of cotton seeds to $\mathrm{Pb}$. Cotton seeds were chemically activated trough the process using a solution of $85 \% \mathrm{H} 3 \mathrm{PO}$. This study aims to determine the optimum weight of activated charcoal an adsoption capacity in optimum condition by using two parameter variations of weight of 0,3; 0,6;0,9; 1,2 and 1,5 grams and $\mathrm{Pb}$ concentration of $10,20,30,40$ and $50 \mathrm{ppm}$ by using a contact time of 30 minutes. $\mathrm{Pb}$ concentration was measured using a spectrophotometer spectro-direct. The result obtained that optimum weight of active charcoal cotton seeds was 1,2 grams with a percentage of 97,76\% uptake an adsorption capacity in optimum condition $\mathrm{Pb}$ was $0,05 \mathrm{mg} / \mathrm{mg}$ activated charcoal.
\end{abstract}

Keywords: Cotton seeds (Ceiba Pentandra L.); Activated Charcoal; Lead (Pb); spectrophotometer spectro-direct

\section{Pendahuluan}

Kapuk merupakan serat yang dihasilkan dari buahnya. Seratnya sangat ringan dan mudah terbakar. Pohon kapuk umumnya tumbuh di kawasan pinggir pantai serta lahanlahan dengan ketinggian 700 meter diatas permukaan laut. Setiap pohon kapuk dewasa dapat menghasilkan antara $4000-5000$ buah per tahun, sehingga dihasilkan biji kapuk sekitar $50 \mathrm{~kg}$ per tahun (Widhianti, 2010)

Sulawesi tengah khususnya Desa Dalaka Kecamatan Sindue Kabupaten Donggala merupakan desa penghasil kapuk terbesar di provinsi Sulawesi Tengah. Masyarakat dalaka yang hanya memanfaatkan kapuknya saja dalam produksi pembuatan kasur dan hanya memanfaatkan biji kapuk sebagai bahan makanan ternak sehingga terlihat biji kapuk tidak bernilai ekonomis. Secara umum, bentuk kulit biji kapuk sama seperti halnya cangkang kulit tumbuhan biji pada umumnya. Biji kapuk memiliki kandungan selulosa $(21,83 \%)$, hemiselulosa $(23,24 \%)$, lignin $(10,37 \%)$ serta mengandung protein, lemak, abu, fosfor dan kalsium. Terdapatnya bahan-bahan tersebut *Korespondensi:

Sri Wahyuni

Program Studi Pendidikan Kimia, Fakultas Keguruan

dan Ilmu Pendidikan, Universitas Tadulako

email: sriwahyuni_1681@yahoo.com

(c) 2016 - Universitas Tadulako

menjadikan biji kapuk berpotensi untuk digunakan sebagai bahan pembuatan arang (Mujnisa, 2007). Selain itu, bila biji kapuk dikelola secara bijak dengan pemahaman dan kesempatan, biji kapuk dapat digunakan untuk kepentingan yang lebih luas daripada itu.

Pencemaran logam pada dasarnya tidak berdiri sendiri, namun dapat terbawa oleh air, tanah dan udara. Apabila semua komponen tersebut telah tercemar oleh senyawa anorganik, maka didalamnya kemungkinan dapat mengandung berbagai logam berat seperti $\mathrm{Cr}, \mathrm{Zn}, \mathrm{Pb}, \mathrm{Cd}, \mathrm{Fe}$ dan sebagainya. Timbal $(\mathrm{Pb})$ mempunyai dampak negatif bagi kesehatan terutama jika kadarnya sudah melebihi batas kadar yang dibutuhkan oleh tubuh. Walaupun pada konsentrasi rendah, efek ion logam berat dapat berpengaruh langsung hingga terakumulasi pada rantai makanan. Seperti halnya sumber-sumber polusi lingkungan lainnya, logam berat tersebut dapat ditransfer dalam jangkauan yang sangat jauh di lingkungan (Darmayanti dkk., 2012).

Beberapa metode yang dapat digunakan untuk menurunkan konsentrasi ion logam berat dalam limbah cair diantaranya adalah adsorpsi, pengendapan, penukar ion dengan menggunakan resin, filtrasi, dan dengan cara penyerapan bahan pencemar oleh adsorben 
baik berupa resin sintetik. maupun karbon aktif (Giequel dkk., 1997). Diantara metode-metode tersebut, adsorpsi merupakan metode yang paling umum dipakai karena memiliki konsep yang lebih sederhana dan dapat diregenerasi serta ekonomis.

Teknik adsorpsi terhadap logam berat telah banyak dilakukan dengan menggunakan berbagai macam adsorben, yaitu Fauzi (2010) melakukan penelitian tentang pembuatan karbon aktif dari sekam padi dengan aktivator $\mathrm{H}_{3} \mathrm{PO}_{4}$, Lestari (2010) juga melakukan penelitian tentang kulitbatang jambu biji sebagai adsorben logam timbal. Selanjutnya Gunawan \& Suhendra (2010) meneliti pembuatan adsorben melalui pemanfaatan batang jagung sebagai arang aktif menggunakan aktivator asam sulfat dengan penggunaannya pada penyerapan ion tembaga (II) dan penggunaan cangkang kelapa sawit sebagai adsorben melalui aktivasi fisika kimia (Meisrilestrati dkk., 2013).

Berdasarkan hal tersebut peneliti mencoba membuat arang aktif yang cukup efisien dari biji kapuk dengan pengaplikasiannya terhadap salah satu logam berat yaitu logam $\mathrm{Pb}$ yang merupakan logam yang mencemari lingkungan khususnya diperairan sehingga pemanfaatan biji kapuk dapat bernilai ekonomis dan maksimal. Penelitian ini bertujuan untuk menentukan berat optimum arang aktif biji kapuk dalam mengadsorpsi logam $\mathrm{Pb}$ dan menentukan kapasitas pada serapan maksimum logam $\mathrm{Pb}$ oleh arang aktif biji kapuk.

\section{Metode}

\section{Alat dan Bahan}

Alat yang digunakan pada penelitian ini yaitu neraca digital, tanur, oven, desikator, gelas ukur $50 \mathrm{~mL}$ dan $100 \mathrm{~mL}$, corong, Erlenmeyer $100 \mathrm{~mL}$, ayakan 60 mesh, gelas kimia, shaker, spatula, batang pengaduk, botol semprot, kertas aluminium foil, labu ukur 50 $\mathrm{mL}$ dan $500 \mathrm{~mL}$, pipet tetes dan instrumen spektrofotometer spektro-direct (Lovibond). Bahan yang digunakan yaitu biji kapuk, asam fosfat $\left(\mathrm{H}_{3} \mathrm{PO}_{4}\right)$ pekat p.a $85 \%$ asam nitrat $\left(\mathrm{HNO}_{3}\right)$ 0,01 M p.a (Merck), aquades, padatan timbal nitrat $\left(\mathrm{Pb}\left(\mathrm{NO}_{3}\right)_{2}\right)$ (Merck), larutan buffer asetat $\mathrm{pH} 5$ (Merck) dan kertas saring Wathman 41 .

\section{Pembuatan arang aktif biji kapuk}

Sebanyak $1 \mathrm{~kg}$ biji kapuk yang sudah tua dibersihkan dan dicuci menggunakan air bersih dan dikeringkan dibawah sinar matahari selama 24 jam. Selanjutnya biji kapuk dikeringkan kembali menggunakan oven dengan suhu $110^{\circ} \mathrm{C}$ selama 5 jam lalu didinginkan pada suhu kamar.

Selanjutnya biji kapuk dimasukkan ke dalam tanur pada suhu $500^{\circ} \mathrm{C}$ selama 1 jam hingga terbentuk arang kemudian dihaluskan dan diayak menggunakan ayakan 60 mesh lalu ditimbang. Kemudian arang biji kapuk diaktivasi selama 24 jam menggunakan larutan $\mathrm{H}_{3} \mathrm{PO}_{4} 85 \%$ sebanyak $150 \mathrm{~mL}$ lalu disaring menggunakan kertas saring. Arang aktif yang diperoleh lalu dicuci dengan aquades hingga $\mathrm{pH}$ netral kemudian dikeringkan menggunakan oven pada suhu $110^{\circ} \mathrm{C}$ selama 4 jam lalu didinginkan di dalam desikator selama 30 menit.

\section{Pembuatan larutan standar $\mathrm{Pb}$ dalam $\mathrm{Pb}\left(\mathrm{NO}_{3}\right)_{2}$ $100 \mathrm{ppm}$ \\ 0,08 gram $\mathrm{Pb}\left(\mathrm{NO}_{3}\right)_{2}$ dilarutkan ke} dalam gelas kimia. Selanjutnya ditambahkan $\mathrm{HNO}_{3}$ 0,01 M sebanyak 2 tetes. Kemudian dimasukkan larutan $\mathrm{Pb}$ ke dalam labu ukur $500 \mathrm{~mL}$ dan tambahkan aquades hingga tanda batas.

Pengaruh variasi berat arang aktif biji kapuk terhadap adsorpsi logam $\mathrm{Pb}$

Arang aktif biji kapuk ditimbang masing - masing sebanyak 0,3 gram, 0,6 gram, 0,9 gram, 1,2 gram dan 1,5 gram dan dimasukkan ke dalam Erlenmeyer kemudian ditambahkan 25 mL larutan $\mathrm{Pb} 100$ ppm ke dalam masingmasing Erlenmeyer dan $5 \mathrm{~mL}$ larutan buffer $\mathrm{pH} 5$ ke dalam masing-masing Erlenmeyer lalu ditutup dengan kertas aluminium foil dan diikat dengan karet kemudian dishaker selama 30 menit. Selanjutnya filtrat dan residu yang diperoleh kemudian dipisahkan dengan penyaringan menggunakan kertas saring lalu konsentrasi larutan diukur dengan spektrofotometer spektro-direct.

Pengaruh variasi konsentrasi larutan terhadap adsorpsi logam Pb oleh arang aktif biji kapuk.

Arang aktif biji kapuk ditimbang dengan berat optimum yang diperoleh dan dimasukkan ke dalam 5 labu erlenmeyer. Kemudian ditambahkan $25 \mathrm{~mL}$ larutan $\mathrm{Pb}$ dengan konsentrasi berturut-turut $10 \mathrm{ppm}, 20$ ppm, 30 ppm, 40 ppm dan 50 ppm ke dalam erlenmeyer dan $5 \mathrm{~mL}$ larutan buffer 5 ke dalam masing-masing Erlenmeyer lalu ditutup dengan kertas aluminium foil dan diikat dengan karet kemudian dishaker selama 30 menit. Selanjutnya filtrat dan residu yang diperoleh kemudian dipisahkan dengan penyaringan lalu konsentrasi larutan diukur dengan 
menggunakan spektrofotometer spektro-direct.

\section{Analisa Data}

Data yang diperoleh dari hasil pengukuran konsentrasi logam $\mathrm{Pb}$ dengan menggunakan spektrofotometer spektro-direct dianalisis menggunakan persamaan (Rudin, 2010):

Konsentrasi timbal dalam persen:

$$
C b=\left(C_{i}-C_{e q}\right)
$$

dimana $\mathrm{Cb}=$ Konsentrasi $\mathrm{Pb}$ yang terserap $(\mathrm{mg} / \mathrm{L}) ; \mathrm{Ci}=$ Konsentrasi $\mathrm{Pb}$ mula - mula $(\mathrm{mg} / \mathrm{L}) ;$ dan $\mathrm{Ceq}=$ Konsentrasi $\mathrm{Pb}$ saat setimbang $(\mathrm{mg} / \mathrm{L})$

\section{Hasil dan Pembahasan}

Biji kapuk yang digunakan adalah biji kapuk yang sudah tua dan disiapkan sebanyak $2 \mathrm{~kg}$. Selanjutnya sebagian dari $2 \mathrm{~kg}$ biji kapuk terlebih dahulu dibersihkan dengan air bersih dan dikeringkan dibawah sinar matahari selama 24 jam. Kemudian biji kapuk dikeringkan kembali menggunakan oven dengan suhu 110 ${ }^{\circ} \mathrm{C}$ selama 5 jam untuk menghilangkan kadar air pada biji kapuk kemudian mendinginkannya pada suhu kamar. Selanjutnya biji kapuk yang telah kering dimasukkan kedalam tanur dengan suhu $500{ }^{\circ} \mathrm{C}$ selama 1 jam hingga terbentuk arang. Hal ini bertujuan untuk melakukan proses pirolisis yang menghasilkan karbon sebagai hasil akhir.

Karbon yang dihasilkan dari pembakaran selulosa dari biji kapuk tersebut yang tidak sempurna mengikuti reaksi umum pembakaran

$$
\mathrm{C}_{8} \mathrm{H}_{9} \mathrm{O}_{\mathrm{O}}+\mathrm{O}_{2(\mathrm{~g})} \longrightarrow \mathrm{C}_{(8)}+\mathrm{CO}_{(\mathrm{g})}+\mathrm{H}_{2} \mathrm{O}_{(\mathrm{g})}
$$

Pembakaran tidak sempurna akan menghasilkan $\mathrm{CO}, \mathrm{H}_{2} \mathrm{O}$ dan $\mathrm{C}$. unsur $\mathrm{C}$ ini yang selanjutnya akan diaktivasi. Namun, sebelum diaktivasi terlebih dahulu arang yang dihasilkan kemudian dihaluskan dan diayak menggunakan ayakan ukuran 60 mesh. Hal ini bertujuan untuk memperkecil ukuran partikel arang biji kapuk sehingga pusat aktif yang ada dipermukaan (pori-pori) menjadi semakin besar, sehingga semakin banyak adsorbat yang terserap (Widhianti, 2010). Selanjutnya berat arang diperoleh sebanyak 70,1 gram.

Proses selanjutnya adalah proses aktivasi arang. Arang yang telah diayak selanjutnya diaktivasi menggunakan larutan $\mathrm{H}_{3} \mathrm{PO}_{4}$ $85 \%$. Proses aktivasi arang dilakukan dengan merendam arang dengan larutan $\mathrm{H}_{3} \mathrm{PO}_{4}$ $85 \%$ sebanyak $150 \mathrm{ml}$ selama 24 jam. Hal ini bertujuan untuk membuka pori-pori permukaan arang dengan cara memecahkan ikatan hidrokarbon atau mengoksidasi molekul - molekul permukaan sehingga arang aktif biji kapuk mengalami perubahan fisika dan kimia yaitu luas permukaannya bertambah besar dan meningkatkan daya serap arang aktif (Rudin, 2011). Mekanisme reaksi aktivasi arang dengan $\mathrm{H}_{3} \mathrm{PO}_{4}$ dapat dilihat pada Gambar 2.

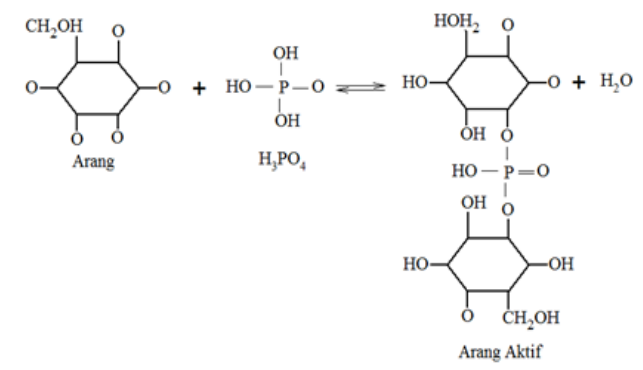

Gambar 1 Reaksi Aktivasi Arang dengan $\mathrm{H}_{3} \mathrm{PO}_{4}$ (Herlina \& Esterlita, 2015)

Dari Gambar 1 dapat diketahui bahwa aktivator $\mathrm{H}_{3} \mathrm{PO}_{4}$ bereaksi dengan arang yang sudah terbentuk kemudian membentuk mikropori pada permukaan yang berfungsi sebagai tempat berlangsungnya adsorpsi. Hal ini semakin membuat permukaan adsorpsi pada arang semakin luas (Herlina \& Esterlita, 2015).

Selanjutnya arang aktif yang diperoleh disaring menggunakan kertas saring kemudian mencuci arang yang telah diaktivasi dengan menggunakan aquades hingga $\mathrm{pH}$ netral. Pencucian dengan menggunakan aquades bertujuan untuk menghilangkan zat-zat pengotor pada arang aktif. Filtrat hasil penyaringan kemudian diuji dengan menggunakan kertas indikator universal yaitu mengukur $\mathrm{pH}$ dari filtrat sampai $\mathrm{pH}$ netral yaitu pada $\mathrm{pH}$ 7. Setelah diperoleh arang aktif pada keadaan $\mathrm{pH}$ netral. Selanjutnya arang aktif dimasukkan kedalam oven pada suhu $110{ }^{\circ} \mathrm{C}$ selama 4 jam untuk melakukan proses pengeringan. Penggunaan suhu 110 ${ }^{\circ} \mathrm{C}$ ini dikarenakan pada suhu tersebut air dapat menguap disebabkan titik didih dari air adalah $100{ }^{\circ} \mathrm{C}$. Selanjutnya tujuan proses pengeringan arang aktif ini adalah untuk menguapkan air pada arang aktif sebab arang bersifat higroskopis yang dapat menyerap air yang terdapat di lingkungannya, karena apabila masih mengandung air dalam pori-pori arang aktif, akan mengganggu interaksi ion logam terhadap pusat aktif arang sebab air akan menutupi pori - pori arang aktif serta akan berkompetisi dengan adsorben untuk mengikat logam (Talunoe, 2014). Selanjutnya berat arang diperoleh sebanyak 40,05 gram.

Pada penelitian ini, menggunakan spektrofotometer spektro-direct pada 
penentuan konsentrasi timbal dalam larutannya melalui dua variasi yaitu variasi berat arang aktif dan variasi konsentrasi larutan $\mathrm{Pb}$ seperti dibawah ini.

\section{Variasi Berat Arang Aktif}

Variasi berat arang aktif ini digunakan untuk penentuan berat optimum arang aktif sebagai adsorben logam $\mathrm{Pb}$. Penentuan berat optimum pada adsorpsi logam $\mathrm{Pb}$ menggunakan arang aktif biji kapuk yang dilakukan pada 5 variasi berat arang aktif biji kapuk yaitu 0,3 gram, 0,6 gram, 0,9 gram,1,2 gram dan 1,5 gram dengan menggunakan waktu kontak selama 30 menit dengan penambahan buffer asetat $\mathrm{pH} 5$.

Penggunaan waktu kontak 30 menit didasarkan pada penelitian mengenai penentuan waktu kontak optimum arang aktif terhadap ion $\mathrm{Pb}$ (II) dan diperoleh waktu kontak optimum yaitu 30 menit yang pada waktu kontak tersebut terjadi adsropsi maksimal terhadap ion $\mathrm{Pb}$ (Imawati \& Adhityawarman, 2015). Selanjutnya penggunaan buffer asetat $\mathrm{pH} 5$ pada tiap larutan didasarkan pada penelitian mengenai penentuan $\mathrm{pH}$ optimum arang aktif terhadap ion $\mathrm{Pb}(\mathrm{II})$ dan diperoleh $\mathrm{pH}$ optimum yaitu $\mathrm{pH} 5$ yang pada $\mathrm{pH}$ tersebut merupakan $\mathrm{pH}$ stabil untuk ion $\mathrm{Pb}(\mathrm{II})$. (Effendi, 2015). Selain itu dikarenakan ion $\mathrm{Pb}(\mathrm{II})$ pada $\mathrm{pH}<5$ tingkat keasaman larutan akan lebih tinggi sehingga pada $\mathrm{pH}$ tersebut cenderung terdapat lebih banyak ion $\mathrm{H}^{+}$dan akan mengganggu proses adsorpsi ion $\mathrm{Pb}$ (II) dan akan terjadi kompetisi antara ion $\mathrm{H}^{+}$ dengan ion $\mathrm{Pb}(\mathrm{II})$ untuk berinteraksi dengan pori pada permukaan arang aktif sedangkan pada keadaan ion $\mathrm{Pb}$ (II) pada $\mathrm{pH}>5$, ion $\mathrm{Pb}$ sudah mulai mengendap membentuk $\mathrm{Pb}(\mathrm{OH})_{2}$ (Muzakkar \& Ratna, 2012). Kenaikan pH akan menurunkan jumlah ion $\mathrm{H}^{+}$sehingga ion $\mathrm{H}^{+}$ yang mengelilingi gugus aktif pada permukaan adsorben berkurang dan gugus aktif mengalami ionisasi sehingga bermuatan negatif (Isagai, 2008). Tabel 1.

Hasil yang diperoleh dapat dilihat pada

Tabel 1 Hasil pengukuran konsentrasi $\mathrm{Pb}$ yang teradsorpsi pada variasi berat arang aktif

biji

\begin{tabular}{cccccc}
\hline No. & Berat (gram) & $\mathrm{C}_{\mathrm{i}}(\mathrm{mg} \mathrm{L})$ & $\mathrm{C}_{\mathrm{eq}}(\mathrm{mg} \mathrm{L})$ & $\mathrm{C}_{\mathrm{b}}(\mathrm{mg} \mathrm{L})$ & $\% \mathrm{~Pb}$ \\
\hline 1. & 0,3 & 118 & $3,58 \pm 0,06$ & $114,42 \pm 0,06$ & $96,97 \pm 0,05$ \\
2. & 0,6 & 118 & $3,26 \pm 0,15$ & $114,74 \pm 0,15$ & $97,23 \pm 0,13$ \\
3. & 0,9 & 118 & $3,09 \pm 0,14$ & $114,91 \pm 0,14$ & $97,38 \pm 0,17$ \\
4. & 1,2 & 118 & $2,64 \pm 0,47$ & $115,36 \pm 0,47$ & $97,76 \pm 0,39$ \\
5. & 1,5 & 118 & $2,72 \pm 0,43$ & $115,28 \pm 0,43$ & $97,69 \pm 0,36$ \\
\hline
\end{tabular}

Dari Tabel 1 terlihat adsorpsi $\mathrm{Pb}$ dipengaruhi oleh berat adsorben. Proses adsorpsi meningkat dari 0,3 gram hingga 1,2 gram sehingga meningkat pula persentase logam $\mathrm{Pb}$ yang teradsorpsi meskipun peningkatan persentase $\mathrm{Pb}$ tidak signifikan. Peningkatan adsorpsi tersebut disebabkan karena bertambahnya jumlah arang aktif yang berinteraksi dengan logam $\mathrm{Pb}$. Terjadinya peningkatan adsorpsi logam timbal pada berat arang aktif 0,3 gram 1,2 gram, karena kerapatan sel pada arang aktif dalam larutan sehingga menghasilkan interaksi yang cukup efektif antara pusat aktif dinding sel arang aktif dengan logam $\mathrm{Pb}$, oleh karena semakin banyak adsorben maka semakin banyak pusat aktif arang yang bereaksi (Rudin, 2011).

Namun, pada berat adsorben 1,5 gram terlihat adsorpsinya mulai menurun. Hal ini dikarenakan ion-ion $\mathrm{Pb}$ yang terdapat di dalam larutan telah teradsorpsi sepenuhnya oleh arang aktif. Selain itu, hal tersebut juga dapat terjadi karena permukaan arang aktif sudah dalam keadaan jenuh dengan ion-ion logam $\mathrm{Pb}$ sehingga peningkatan berat arang aktif relatif tidak lagi mempengaruhi peningkatkan penyerapan ion logam oleh arang aktif tersebut (Rudin, 2011).

Sesuai dengan penelitian ebelumnya mengatakan bahwa jumlah adsorben mempengaruhi prsoses adsorpsi dimana semakin bertambahnya berat adsoben menyebabkan adsorben telah mencapai titik jenuh jika permukaannya telah terisi oleh adsorbat (Anjani \& Koestiari, 2014).

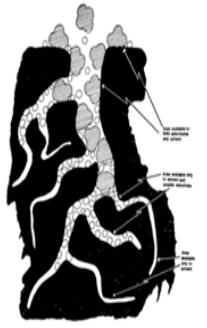

Gambar 2 Proses adsorpsi Pb(II) kedalam pori-pori adsorben (Lestari, 2010).

Pada Gambar 2 terlihat $\mathrm{Pb}$ terperangkap kedalam rongga atau pori-pori adsorben. Hal tersebut dikarenakan arang aktif memiliki permukaan lebih luas dan pori-porinya yang terbuka sehingga mampu mengadsorpsi logam $\mathrm{Pb}$. Semakin luas permukaan pori-porinya, maka semakin tinggi pula daya adsorpsinya (Wahjuni \& Kostradiyanti, 2008).

Berdasarkan Tabel 1 maka diketahui berat optimum arang aktif biji kapuk terhadap 
adsorpsi logam timbal yaitu pada 1,2 gram arang aktif dengan persentase serapan yaitu $97,76 \%$.

Variasi Konsentrasi terhadap adsorpsi larutan Pb

Variasi konsentrasi larutan $\mathrm{Pb}$ ini digunakan untuk mengetahui hubungan daya adsorpsi logam $\mathrm{Pb}$ dalam berbagai konsentrasi sekaligus mengetahui kapasitas pada serapan maksimum arang aktif sebagai adsorben logam $\mathrm{Pb}$. Penentuan kapasitas pada serapan maksimum menggunakan arang aktif biji kapuk dilakukan pada 5 variasi konsentrasi larutan timbal yaitu $10 \mathrm{ppm}, 20 \mathrm{ppm}, 30 \mathrm{ppm}, 40 \mathrm{ppm}$ dan 50 ppm dengan menggunakan waktu kontak selama 30 menit dengan penambahan buffer asetat $\mathrm{pH} 5$.

Hasil yang diperoleh dapat dilihat pada Tabel 2.

Tabel 2 Hasil pengukuran pada variasi konsentrasi larutan timbal terhadap adsorpsi arang aktif biji kapuk.

\begin{tabular}{cccccc}
\hline No. & Berat (gram) & $C_{i}(\mathrm{mgL})$ & $C_{\mathrm{eq}}(\mathrm{mg} \mathrm{L})$ & $C_{6}(\mathrm{mg} \mathrm{L})$ & $0, \mathrm{Pl}$ \\
\hline 1. & 1,2 & 17,4 & $1,03 \pm 0,21$ & $16,37 \pm 0,21$ & $94,06 \pm 1,19$ \\
2. & 1,2 & 31,2 & $1,65 \pm 0,09$ & $29,55 \pm 0,09$ & $94,71 \pm 0,22$ \\
3. & 1,2 & 41,1 & $2,09 \pm 0,19$ & $39,01 \pm 0,19$ & $94,91 \pm 0,46$ \\
4. & 1,2 & 51,2 & $1,85 \pm 0,10$ & $49,35 \pm 0,10$ & $96,38 \pm 0,19$ \\
5. & 1,2 & 64,4 & $2,30 \pm 0,12$ & $62,10 \pm 0,12$ & $96,43 \pm 0,19$ \\
\hline
\end{tabular}

Dari hasil penelitian yang disajikan pada Tabel 2, terlihat bahwa adsorpsi $\mathrm{Pb}$ oleh arang aktif biji kapuk dipengaruhi oleh konsentrasi larutan. Semakin besar konsentrasi awal larutan maka semakin meningkat pula adsorpsi $\mathrm{Pb}$. Adsorpsi $\mathrm{Pb}$ meningkat pada konsentrasi 10 ppm sampai $50 \mathrm{ppm}$. Hasil tersebut sejalan dengan penelitian tentang penyerapan ion $\mathrm{Pb}$ oleh arang aktif dan mendapatkan bahwa penyerapan ion logam $\mathrm{Pb}$ terus meningkat secara linear meskipun konsentrasi larutan terus dinaikkan (Muzakkar \& Ratna, 2012).

Penyerapan secara kimia terjadi karena terbentuknya ikatan antara pusat aktif yang terdapat pada permukaan adsorben. Dalam hal ini, adsorben belum jenuh dengan $\mathrm{Pb}$ yang teradsorpsi. Maka, dengan meningkatkan konsentrasi ion logam timbal yang teradsorpsi oleh adsorben akan meningkat secara linear dan apabila pusat aktif telah jenuh dengan ion logam, maka peningkatan konsentrasi ion logam relatif tidak meningkatkan adsorpsi ion logam oleh adsorben (Amansyah, 2008).
Dari uraian diatas, diperoleh bahwa adsorpsi optimum logam $\mathrm{Pb}$ pada penelitian ini, terjadi pada konsentrasi larutan $\mathrm{Pb} 64,4$ $\mathrm{mg} / \mathrm{L}$ dengan persentase serapan $\mathrm{Pb}$ yaitu 96,43\% menggunakan berat optimum yang diperoleh yaitu 1,2 gram dan kapasitas serapan maksimum arang aktif dalam menyerap logam sebesar $0,05 \mathrm{mg} \mathrm{Pb} / \mathrm{mg}$ arang aktif. Hal ini berarti bahwa tiap $1 \mathrm{mg}$ arang aktif biji kapuk mampu mengadsorpsi ion timbal sebesar 0,05 $\mathrm{mg}$.

\section{Kesimpulan}

Berat optimum yang diperlukan arang aktif biji kapuk untuk menyerap logam $\mathrm{Pb}$ adalah sebesar 1,2 gram dengan persentase logam $\mathrm{Pb}$ yang teradsorpsi yaitu $97,76 \%$ serta kapasitas serapan maksimum arang aktif biji kapuk dalam menyerap logam $\mathrm{Pb}$ yaitu $0,05 \mathrm{mg} / \mathrm{g}$ pada konsentrasi larutan $\mathrm{Pb}$ yaitu 64,4 mg/L.

\section{Ucapan Terima Kasih}

Penulis mengucapkan terima kasih kepada kepala Laboratorium Kimia Lanjut Fakultas Keguruan dan Ilmu Pendidikan Universitas Tadulako dan kepada kepala Laboratorium Agroteknologi Fakultas Pertanian Universitas Tadulako serta semua pihak yang telah membantu dalam pelaksanaan penelitian ini.

\section{Referensi}

Amansyah, M. S. D. (2008). Kapasitas adsorpsi ampas tahu terhadap ion Cr(VI) dalam air. Skripsi Pendidikan Kimia, Fakultas Keguruan dan Ilmu Pendidikan, Universitas Tadulako, Palu.

Anjani, R. K., \& Koestiari, T. (2014). Penentuan massa dan waktu kontak optimum adsorpsi karbon granular sebagai logam berat $\mathrm{Pb}(\mathrm{II})$ dengan pesaing ion $\mathrm{Na}^{+}$. Journal of Chemistry, 3(3), 159-163.

Darmayanti, Rahman, N., \& Supriadi. (2012). Adsorpsi timbal (Pb) dan zink $(\mathrm{Zn})$ dari larutannya menggunakan arang hayati (biocharcoal) kulit pisang kepok berdasarkan variasi pH. Jurnal Akademika Kimia, 1(4), 159-165.

Effendi, R. (2015). Adsorpsi logam Ni(II) dan $\mathrm{Pb}(\mathrm{II})$ dengan menggunakan arang sekam 
padi yang teraktivasi $\mathrm{H}_{3} \mathrm{PO}_{4}$. Yogyakarta: Universitas Islam Negeri Sunan Kalijaga.

Fauzi, M. A. (2010). Pembuatan karbon aktif dari sekam padi dengan aktivator $\mathrm{H}_{3} \mathrm{PO}_{4}$. Skripsi Teknik Kimia. Semarang: Fakultas Teknik Universitas Diponegoro.

Giequel, L., Wolbert, D., \& Laplanche, A. (1997). Adsorption of antrazine by powdered activated carbon, influence of dissolved organic and mineral matter of natural water. Journal Environmental Science and Technology, 18, 467-478.

Gunawan, E. T., \& Suhendra, D. (2010). Pembuatan karbon aktif dari sekam padi dengan aktivator $\mathrm{H}_{3} \mathrm{PO}_{4}$. Jurnal Makara Sains, 14(1), 22-26.

Herlina, N., \& Esterlita, M. O. (2015). Pengaruh penambahan aktivator $\mathrm{ZnCl}$, $\mathrm{KOH}$ dan $\mathrm{H}_{3} \mathrm{PO}_{4}$ dalam pembuatan karbon aktif dari pelepah aren (arenga pinnata). Jurnal Teknik Kimia, 4(1), 47-52.

Imawati, A., \& Adhityawarman. (2015). Kapasitas adsorpsi maksimum ion $\mathrm{Pb}(\mathrm{II})$ oleh arang aktif ampas kopi teraktivasi $\mathrm{HCl}$ dan $\mathrm{H}_{3} \mathrm{PO}_{4}$. Jurnal Kimia, 4(2), 50-61.

Isagai, H. (2008). Adsorption of zinc(II) and copper(II) to shirasu (pyroclastic flow). Journal Analytical Science, 24, 395-399.

Lestari, S. (2010). Pengaruh berat dan waktu kontak untuk adsorpsi timbal (II) oleh adsorben kulit batang jambu biji (psidium guajava L.). Jurnal Kimia Mulawarman, 8(1), 6-9.

Meisrilestrati, Y., Khomaini, R., \& Wijayanti. (2013). Pembuatan arang aktif dari cangkang kelapa sawit dengan aktivasi secara fisika, kimia dan fisika-kimia. Jurnal Konversi, 2(1), 46-51.

Mujnisa, A. (2007). Kecernaan bahan kering in vitro, proporsi molar asam dan produksi gas pada kulit coklat, biji kapuk, kulit markisa, dan biji markisa. Skripsi. Fakultas Peternakan Universitas Hasanudin, Makassar.

Muzakkar, M. Z., \& Ratna. (2012). Studi adsorpsi ion logam timbal(II) dengan menggunakan arang aktif kulit biji jambu mete. Jurnal Kimia dan Pendidikan Kimia, 1(2), 132-141.

Rudin, R. L. (2011). Pembuatan biocharcoal dari kulit pisang kepok untuk penyerapan logam timbal(Pb) dan logam seng $(Z n)$. Skripsi Pendidikan Kimia, Fakultas Keguruan dan Ilmu Pendidikan Universitas Tadulako, Palu.

Talunoe, O. (2014). Pemanfaatan arang aktif kulit kacang tanah sebagai adsorben besi $(\mathrm{Fe})$ pada air sumur di Desa Pendolo Kecamatan Pamona selatan Kabupaten Poso. Skripsi Kimia. Palu: Fakultas Matematika dan Ilmu Pengetahuan Alam Universitas Tadulako.

Wahjuni, S., \& Kostradiyanti, B. (2008). Penurunan angka peroksida minyak kelapa tradisional dengan adsorben arang sekam padi ir 64 yang diaktifkan dengan kalium hidroksida. Jurnal Kimia, 2(1), 57-60.

Widhianti, W. D. (2010). Pembuatan arang aktif dari biji kapuk (ceiba pentandra L.) sebagai adsorben zat warna rhodamin $B$. Skripsi Kimia, Fakultas Sains dan Teknologi Universitas Airlangga, Surabaya. 